\title{
Protective effect of Chresta martii extract against indomethacin-induced gastric lesions in mice
}

\author{
A. A. R. Silva $\cdot$ M. M. Bezerra $\cdot$ H. V. Chaves $\cdot$ K. M. A. Pereira $\cdot$ \\ J. A. Aguiar - V. P. T. Pinto - C. Abbet - C. A. Simões-Pires - E. S. Franco • \\ A. T. Henriques $\cdot$ K. Hostettmann $\cdot$ M. B. S. Maia
}

Received: 2 February 2012/ Accepted: 12 March 2012/Published online: 27 March 2012

(C) The Japanese Society of Pharmacognosy and Springer 2012

\begin{abstract}
Chresta martii (Asteraceae) is a plant found in the Xingó region (semi-arid area) in Northeastearn Brazil, and is recognized by the local population as a traditional herb used to treat gastric diseases. This is the first report of the chemical composition, acute toxicity, and gastroprotective effect in mice of the hydroalcoholic extract (HAE) from the aerial parts (leaves and flowers) of Chresta martii. Animals received HAE doses from 10 to $2000 \mathrm{mg} / \mathrm{kg}$, i.p. or 50 to $3000 \mathrm{mg} / \mathrm{kg}$, p.o.) and were observed over $48 \mathrm{~h}$ for toxicity signs and mortality; sub-chronic toxicity was evaluated
\end{abstract}

A. A. R. Silva $(\square) \cdot$ M. M. Bezerra · H. V. Chaves

K. M. A. Pereira - J. A. Aguiar

Laboratory of Pharmacology of Sobral (LaFS), Federal

University of Ceará Brazil, Avenida Comandante Maurocélio

Rocha Pontes, 100, Sobral, CE 62042-280, Brazil

e-mail: alfredodentista@gmail.com

M. M. Bezerra

e-mail: mirnabrayner@gmail.com

H. V. Chaves

e-mail: helliadachaves@yahoo.com.br

K. M. A. Pereira

e-mail: karuzaalves@yahoo.com.br

J. A. Aguiar

e-mail: jordana_aguiar@hotmail.com

V. P. T. Pinto

Laboratory of Biochemistry of Sobral, Master of Biotechnology Degree Program, Federal University of Ceará, Av. Comandante Maurocélio Rocha Pontes, 100, Sobral, CE 62042-280, Brazil e-mail: pintovicente@gmail.com

C. Abbet · C. A. Simões-Pires · K. Hostettmann

School of Pharmaceutical Sciences, University of Geneva,

University of Lausanne, 30 Quai Ernest-Ansermet,

1211 Geneva, Switzerland

e-mail: claudia.avello@unige.ch through 14 days treatment with once-daily HAE doses (400 mg/kg, p.o.). The gastroprotective effect of HAE was demonstrated on the indomethacin-induced gastric ulcer model after the administration of extracts. Data comparison of ulcer index averages between saline and HAE (100 or $400 \mathrm{mg} / \mathrm{kg}$, p.o.) groups showed significant $(P<0.01)$ inhibition (71.73 and $76.72 \%$, respectively) of indomethacin-induced gastric lesions. Histological analyses showed significant $(P<0.05)$ inhibition of leukocyte migration in HAE-treated groups. A fingerprint of the HAE obtained by

\author{
C. A. Simões-Pires \\ e-mail: christian.abbet@unibas.ch \\ K. Hostettmann \\ e-mail: kurt.hostettmann@unige.ch \\ E. S. Franco - M. B. S. Maia \\ Laboratory of Pharmacology of Bioactive Products, \\ Department of Physiology and Pharmacology, Federal \\ University of Pernambuco, Av. Prof. Moraes Rego 1235, \\ Recife, PE 50670-901, Brazil \\ e-mail: eryvelton_franco@hotmail.com \\ M. B. S. Maia \\ e-mail: maria.maia@pq.cnpq.br \\ A. T. Henriques \\ Programa de Pós-Graduação em Ciências Farmacêuticas, \\ Faculdade de Farmácia, UFRGS, Av. Ipiranga 2752, \\ Porto Alegre, RS 90610-000, Brazil \\ e-mail: amelia@farmacia.ufrgs.br
}


HPLC/UV/MS analysis showed major peaks characteristic of sesquiterpene lactones. Compound $\mathbf{1}$ was isolated and elucidated as a new natural product. Its capacity to prevent leukocyte chemotaxis was demonstrated in vitro, corroborating the pharmacological effects observed for $C$. martii HAE.

Keywords Chresta martii - Asteraceae - Sesquiterpene lactones - Gastric ulcer

\section{Introduction}

Despite progress in diagnosis and treatment, peptic ulcer disease remains a common reason for hospitalization and operation. Gastric ulcers may arise from several factors including infection (Helicobacter pylori) together with an imbalance between aggressive (acid, pepsin) and protective factors (prostaglandin, mucus and bicarbonate, gastric mucosal blood flow and motility) [1].

The current medicinal treatment of peptic ulcer is generally based on the inhibition of gastric acid secretion by $\mathrm{H}_{2}$-receptor antagonists (ranitidine, cimetidine) and antimuscarinics, as well as on acid-independent therapy provided by sucralfate and bismuth. In the case of $H$. pylori infection, antibiotics are also used. Drugs providing antisecretory activity coupled with cytoprotective effects could represent a promising approach for the successful treatment of peptic gastric ulcer [2].

In recent years, there has been growing interest in alternative therapies and the use of natural products, especially those derived from plants. In traditional medicine, several plants and herbs have been used to treat gastrointestinal disorders [3].

In this regard, Chresta martii (DC.) H. Rob. (Asteraceae), found in the Xingó region (semi-arid area) in Northeastern Brazil, whose genus is considered a synonym for Argyrovernonia [4], is recognized by the local population as a traditional herb used to treat gastric diseases [5-7]. This plant has recently been studied botanically and considered as a new species [8] and this is the first report of its chemical profiling and pharmacological properties. The acute toxicity profile of hydroalcoholic extract (HAE) from C. martii, the evaluation of its antiulcerogenic effect, as well as its phytochemical analysis with the isolation of a new active natural product is reported here.

\section{Materials and methods}

Animals

Male Swiss mice (25-30 g) were housed at $22 \pm 2{ }^{\circ} \mathrm{C}$ under a 12/12-h light/dark cycle, and food and water were supplied ad libitum. Animals were fasted for 18-24 h before the start of experiments. All efforts were made to minimize animal suffering and the number of animals used. All animal treatments and surgical procedures were performed in accordance with the "Guide for the Care and Use of Laboratory Animals" from the Brazilian Science Society in Laboratory Animals (SBCAL). All experiments were in accordance with the Guidelines for the Care and Use of Laboratory Animals and were approved by Committee on Animal Ethics (EAEC), Federal University of Pernambuco (process \# 23076009313/2003-04).

\section{Plant material and extract preparation}

Aerial parts (leaves and flowers) of $C$. martii were collected on 31 July in the Xingó region, Sergipe, Brazil (longitude -37.940 and latitude ranging from -9.5563 to -9.5548 , altitude $130 \mathrm{~m}$ ). After its authentication by Dr. Nádia Roque (Botany Department of Biology InstituteFederal University of Bahia, Brazil) a voucher specimen (protocol \# 14602) was deposited in Vale do Acaraú State University herbarium (Sobral, Ceará, Brazil).

Air-dried and powdered aerial parts of the plant (100 g) were extracted using $50 \%$ ethanol at room temperature $\left(28 \pm 3{ }^{\circ} \mathrm{C}\right)$ for $48 \mathrm{~h}$. After filtration, the dark green solution was concentrated at $50{ }^{\circ} \mathrm{C}$ under reduced pressure to dryness and kept in a freezer. Fresh dilution of dried extract in saline solution $(0.9 \% \mathrm{NaCl})$ was prepared on the day of experiments, and administered orally or intraperitoneally in different doses.

\section{Acute toxicity study}

The intraperitoneal (i.p.) or enteral (p.o.) acute toxicity $\mathrm{LD}_{50}$ of $C$. martii HAE was evaluated in mice $(n=10 /$ group) as described previously [9]. Ranging doses (10-2000 mg/kg, i.p. or 50-3000 mg/kg, p.o.) or saline solution $(5 \mathrm{~mL} / \mathrm{kg}$ p.o.) were administered to the animals as a single dose. Animals were observed over a 48-h period for toxicity signs and mortality.

Sub-chronic toxicity study

Body mass loss, liver weight alteration, blood cell count alterations and the biochemical parameters aspartate aminotransferase (AST), alanine aminotransferase (ALT), amylase and lipase were evaluated after once-daily subchronic treatment of HAE (400 mg/kg, p.o.) or saline solution $(5 \mathrm{~mL} / \mathrm{kg}$ p.o.) for fourteen consecutive days. On the 15th day, all the animals were anesthetized with tribromoethanol (200 mg/kg, i.p.), and blood samples were collected from the retro-orbital plexus. Hematology analysis was performed using an automated hematology 
analyzer (Pentra 80, Horiba ABX, Montpellier, France). Blood samples were analyzed to measure the following parameters: erythrocyte count, hemoglobin concentration, hematocrit, platelet count, leukocyte count, and differential cell count (neutrophils, monocytes and lymphocytes). For serum biochemistry analysis, the blood was centrifuged at $3000 \mathrm{~g}$ for $15 \mathrm{~min}$ after collection. The serum samples were stored at $-80{ }^{\circ} \mathrm{C}$ prior to analysis. The following serum biochemistry parameters were determined by enzymatic and colorimetric tests from Labtest Diagnóstica (Lagoa Santa/MG, Brazil): AST, ALT, amylase and lipase. After killing, the liver was removed and weighed. Spleen, kidney and heart were macroscopically analyzed for possible ulcerative lesions or hemorrhaging.

Indomethacin-induced gastric lesions

Gastric ulceration was induced in 24-h fasted mice by the administration of indomethacin $[40 \mathrm{mg} / \mathrm{kg}$, subcutaneously (s.c.)]. Mice (6 per group) were pre-treated with HAE (100 or $400 \mathrm{mg} / \mathrm{kg}$, p.o.), omeprazole (30 mg/kg, p.o.), used as a positive control, or saline $(5 \mathrm{~mL} / \mathrm{kg}$; p.o.) $1 \mathrm{~h}$ before the challenge. A non-treated group (no indomethacin) was used as control for histological analyses. The animals were killed in a $\mathrm{CO}_{2}$ chamber $6 \mathrm{~h}$ after the ulcerogenic procedure. The stomach was removed and opened along its greater curvature. The ulcer index was evaluated using the quantitative method for assessing the extent of experimental gastric erosions and ulcers as described by Szabo et al. [10]. The percentage inhibition was calculated in relation to the saline group according to the following formula: \%inhibition $=$ UIt/UIs $\times 100$, where UIt and UIs correspond to ulcer index of treated and ulcer index of saline groups, respectively.

\section{Histopathological analysis}

The H\&E-stained gastric samples were semi-quantitatively evaluated for inflammatory infiltration to provide a $(0-3)$ score grade: 0 , no infiltration; 1 , very mild infiltration; 2 , mild infiltration; 3, moderate infiltration; and 4, marked infiltration. These observations were made by an experienced pathologist who was blinded to the treatment protocol.

\section{Statistical analysis}

All values are expressed as mean \pm SEM. For macroscopic (ulcer index) and histological assessment, the Kruskal-Wallis nonparametric test was used, followed by Dunn's test for multiple comparisons. Student's $t$-test was used to evaluate sub-chronic toxicity data. $P<0.05$ was considered statistically significant.
HPLC/UV/APCI-MS analysis

The HPLC/UV/APCI-MS analysis of $C$. martii HAE was performed on an HP-1100 liquid chromatography system (Hewlett-Packard, Palo Alto, CA, USA) equipped with a binary pump, a DAD and an autosampler. MS analyses were made on a Finnigan MAT (San Jose, CA, USA) LCQ ion trap mass with an atmospheric pressure chemical ionization (APCI) interface, with the following conditions: capillary temperature, $150{ }^{\circ} \mathrm{C}$; vaporizer temperature, $370{ }^{\circ} \mathrm{C}$; positive mode; sheath gas flow, 60 psi (414 kPa); corona needle current, $5 \mu \mathrm{A}$; collision energy, $15 \mathrm{eV}$. The separation was achieved on a Waters NovaPak $\mathrm{C}_{18}$ column $(250 \times 4.6 \mathrm{~mm}$ i.d.; $5 \mu \mathrm{m})$ eluted with a linear gradient of methanol-water containing $0.1 \%$ formic acid from 10:90 to 100:0 in $40 \mathrm{~min}$. The flow rate was $1 \mathrm{~mL} / \mathrm{min}$; UV spectra were recorded at 210, 254 and $366 \mathrm{~nm}$.

Centrifugal partition chromatography

Fractionation was conducted on a counter-current chromatograph CCC-IOOO (Pharma-Tech Research Corporation, Baltimore, MD, USA) equipped with dynamic coils of $650 \mathrm{~mL}$ total volume. The rotation speed was set at $1000 \mathrm{rpm}$. Two LC-300 pumps (Scientific Systems Inc., State College, PA, USA) were used to pump either upper or lower phase into the coils at a flow rate of $3.0 \mathrm{~mL} / \mathrm{min}$ for each phase. The HAE was diluted in $30 \mathrm{~mL}$ of a mixture of upper and lower phases (1:1) and introduced through the injection loop. Crude extract $(9 \mathrm{~g})$ was chromatographed using the solvent system chloroform-methanol-water (45:11:44) with the upper phase as the mobile phase, followed by phase inversion after $6 \mathrm{~h}$. By this method, the extract was first fractionated into seven major fractions (AI-AVII).

\section{Column liquid chromatography}

Fraction AII ( $2 \mathrm{~g}$ ) was chromatographed on a silica gel 60 (63-200 $\mu \mathrm{m}$, Merck, Germany) column $(750 \times 20 \mathrm{~mm})$. The mobile phase consisted of hexane, ethyl acetate and methanol in increasing polarity proportions. From the 24 fractions obtained, compound $\mathbf{1}(50 \mathrm{mg})$ could be isolated (Fig. 3).

\section{NMR analyses}

${ }^{1} \mathrm{H}$ and ${ }^{13} \mathrm{C}$ NMR spectra were recorded on a Unity Inova 500 spectrometer at 500 and $125 \mathrm{MHz}$, respectively, with the compound dissolved in $\mathrm{CD}_{2} \mathrm{Cl}_{2}$. Chemical shifts were recorded in ppm with $\delta$ relative to tetramethylsilane (TMS) as internal standard. 


\section{Compound 1}

${ }^{1} \mathrm{H}-\mathrm{NMR}(500 \mathrm{MHz}), \mathrm{CD}_{2} \mathrm{Cl}_{2}: \delta 1.36(3 \mathrm{H}, \mathrm{s}, \mathrm{H}-15), 1.38$ (3 H, s, H-14), 2.04 (1H, ddd, H-1), $2.51(1 \mathrm{H}, \mathrm{m}, \mathrm{H}-1), 2.54$ (H, d, H-2), 2.62 (H, dd, H-2), 2.73 (1H, ddd, H-5), 2.83 $(1 \mathrm{H}, \mathrm{dd}, \mathrm{H}-5), 4.51(2 \mathrm{H}, \mathrm{d}, \mathrm{H}-13), 5.43(1 \mathrm{H}, \mathrm{d}, \mathrm{H}-6), 5.83$ (1H, s, H-9).

${ }^{13} \mathrm{C}-\mathrm{NMR}(125 \mathrm{MHz}), \mathrm{CD}_{2} \mathrm{Cl}_{2}: \delta 26.7(\mathrm{C}-14), 27.2(\mathrm{C}-15)$, 33.9 (C-2), 38.7 (C-1), 47.5 (C-5), 56.0 (C-13), 67.2 (C-6), 74.7 (C-10), 76.2 (C-4), 113.6 (C-9), 121.6 (C-11), 145.1 (C-8), 146.7 (C-7), 168.5 (C-12), 213.1 (C-3).

HRESI/MS 295.1182 [M+H] $]^{+}$, calculated for $\mathrm{C}_{15} \mathrm{H}_{19} \mathrm{O}_{6}$.

In-vitro inhibition of neutrophil chemotaxis

C. martii HAE and compound 1 were investigated for their ability to inhibit neutrophil chemotaxis in vitro. This evaluation was performed using Boyden's method [11] modified by Zigmond and Hirsch [12].

The collection of chemotactic factor, the collection and preparation of neutrophils and the determination of their migration through the filters were conducted as previously described [13].

Readings were taken for 10 fields of two filters for each sample, and the result was expressed as mean $\pm \mathrm{SD}$. The chemotaxis experiment was analyzed using Student's $t$ test. $P<0.05$ was considered statistically significant, and $P<0.001$ was considered highly significant.

\section{Results}

Acute toxicity assay

HAE $(50,100,2000$ or $3000 \mathrm{mg} / \mathrm{kg}$ ) administered orally (p.o.) did not result in mortality or altered pathognomonic behavior of the central nervous system. Similarly, low doses of HAE (10 or $100 \mathrm{mg} / \mathrm{kg}$ ) injected intraperitoneally (i.p.) did not change animals' behavior. However, HAE $(1000 \mathrm{mg} / \mathrm{kg}$, i.p.) caused 2 deaths up to $6 \mathrm{~h}$ after the treatment. Furthermore, HAE $(2000 \mathrm{mg} / \mathrm{kg}$; i.p.) caused more than $50 \%$ of mortality up to $6 \mathrm{~h}$ after the treatment, followed by 2 and 1 deaths over 24 and $36 \mathrm{~h}$, respectively, from the beginning of the assay. All deaths were preceded by reduction of locomotion and eyelid ptosis.

\section{Sub-chronic toxicity essay}

HAE (400 mg/kg, p.o.) treatment for 14 days did not alter blood cell counts, hemoglobin, hematocrit, or liver mass. No macroscopic alterations were observed in internal organs. Indicators of pancreatic function (amylase and lipase) were not altered. ALT and AST values were significantly different from the saline group (Table 1). The body mass curve of the HAE-treated group was not significantly different from that of the saline-treated group (Fig. 1).

\section{Effect of HAE on ulcer index}

Indomethacin administration $(40 \mathrm{mg} / \mathrm{kg}$, s.c.) produced acute hemorrhagic damage. HAE (100 or $400 \mathrm{mg} / \mathrm{kg}$, p.o.) significantly reduced $(P<0.001)$ the gastric lesion score compared to the saline group. Gastric protection by HAE was similar to the effects observed with omeprazole $(30 \mathrm{mg} / \mathrm{kg}$, p.o.) (Table 2).

Histopathological analysis

When compared to the non-treated group (no indomethacin) (Fig. 2a), the gastric mucosa of the saline group (saline + indomethacin) showed marked inflammatory cell accumulation together with disruption of the superficial layers (Fig. 2b). HAE (100 mg/kg) attenuated mucosal erosion as shown in Figure 2c. Histological analysis of omeprazole (30 mg/kg, p.o.) and HAE (100 and $400 \mathrm{mg} / \mathrm{kg}$ ) groups revealed a significant $(P<0.05)$ decrease in inflammatory cell infiltrate $[1(0-1), 1(0-1)$ and $1(0-1)]$, respectively (Table 3 ).

Phytochemical analysis

A fingerprint of the HAE obtained by HPLC/UV/MS analysis is presented in Figure 3. Major peaks were detected in the extract and the presence of flavonoids was excluded. Compounds presented similar UV spectra with a maximum at c. $280 \mathrm{~nm}$ and a slight shoulder at $220 \mathrm{~nm}$, which is characteristic of sesquiterpene lactones [14]. The mass spectra of some compounds, such as $\mathbf{1}$, showed a low base peak at 295.1, corroborating the range of mass for sesquiterpene lactones.

\section{Compound 1}

Compound 1 could be purified and elucidated as a new sesquiterpene lactone based on the analyses of its spectroscopic data. The ${ }^{1} \mathrm{H}$ and ${ }^{13} \mathrm{C}$ NMR data, together with HMBC correlations, are presented in Table 4.

In-vitro inhibition of neutrophil chemotaxis

When investigated for the ability to reduce leukocyte migration in vitro, HAE significantly reduced the migration distance $(P<0.05)$ at $100 \mu \mathrm{g} / \mathrm{mL}$. At the same concentration, the isolated sesquiterpene lactone (compound 1) was able to inhibit leukocyte migration with high significance $(P<0.001)$, which was comparable to the positive control indomethacin (Fig. 4). 
Table 1 Effects of HAE on blood parameters (AST, ALT, amylase, lipase and cell count) and liver mass after once-daily sub-chronic treatment of HAE or saline solution for fourteen consecutive days
Data are presented as mean \pm SEM. Student's $t$ test HAE Chresta martii hydroalcoholic extract ${ }^{\#} P<0.05$ versus saline group

\begin{tabular}{lcc}
\hline Blood parameter/treatment & Saline $(5 \mathrm{~mL} / \mathrm{kg}$ p.o. $)$ & HAE $(400 \mathrm{mg} / \mathrm{kg}$ p.o.) \\
\hline AST (U/L) & $80.69 \pm 4.33$ & $110.3 \pm 7.24^{\#}$ \\
ALT (U/L) & $51.36 \pm 5.54$ & $91.79 \pm 8.43^{\#}$ \\
Amylase (U/dL) & $733.2 \pm 11.48$ & $683.5 \pm 17.92$ \\
Lipase (U/dL) & $276.0 \pm 5.86$ & $268.5 \pm 13.73$ \\
Erythrocyte $\left(10^{6} / \mathrm{mm}^{3}\right)$ & $7.676 \pm 0.17$ & $7.793 \pm 0.17$ \\
Hemoglobin $(\mathrm{g} / \mathrm{dL})$ & $12.84 \pm 0.34$ & $13.14 \pm 0.30$ \\
Hematocrit $(\%)$ & $38.67 \pm 1.11$ & $40.26 \pm 1.05$ \\
Total leukocytes $\left(\mathrm{cells}^{3} / \mathrm{mm}^{3}\right)$ & $2,080 \pm 196.0$ & $2,471 \pm 259.8$ \\
Neutrophils $\left(\mathrm{cells} / \mathrm{mm}^{3}\right)$ & $211.9 \pm 45.35$ & $181.3 \pm 66.89$ \\
Lymphocytes $\left(\mathrm{cells} / \mathrm{mm}^{3}\right)$ & $1,431 \pm 86.20$ & $1,974 \pm 212.1$ \\
Monocytes $\left(\mathrm{cells} / \mathrm{mm}^{3}\right)$ & $437.3 \pm 95.71$ & $316.4 \pm 72.83$ \\
Platelets $\left(\mathrm{mm}{ }^{3}\right)$ & $601,300 \pm 43,376$ & $514,857 \pm 56,340$ \\
Liver mass $(\mathrm{g})$ & $2.120 \pm 0.067$ & $1.925 \pm 0.069$ \\
\hline
\end{tabular}

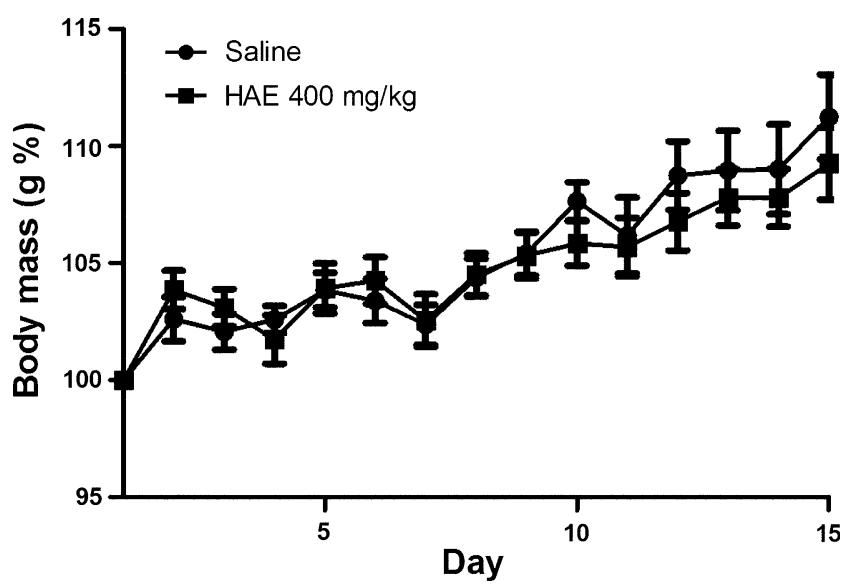

Fig. 1 Body mass evolution of mice treated with HAE $(400 \mathrm{mg} / \mathrm{kg})$ for 14 days. Results are expressed as percentage of initial mass mean. There were no significant differences between saline and HAE-treated groups during the experiment

Table 2 Effects of HAE on the ulcer index (macroscopic analysis) inhibition after indomethacin challenge

\begin{tabular}{lrl}
\hline Treatments & Ulcer index & \% Inhibition \\
\hline Saline & $22.25 \pm 1.8$ & \multicolumn{1}{l}{-} \\
Omeprazole $30 \mathrm{mg} / \mathrm{kg}$, p.o. & $9.31 \pm 2.0$ & $58.15^{*}$ \\
HAE $100 \mathrm{mg} / \mathrm{kg}$, p.o. & $10.09 \pm 1.6$ & $54.66^{*}$ \\
HAE $400 \mathrm{mg} / \mathrm{kg}$, p.o. & $4.16 \pm 1.2$ & $81.30^{*}$
\end{tabular}

Kruskal-Wallis nonparametric test followed by Dunn's test was used for multiple comparisons of macroscopic assessment

HAE Chresta martii hydroalcoholic extract

$* P<0.01$ versus saline group

\section{Discussion}

In the acute toxicity study, all the animals treated orally remained alive and did not manifest any significant visible signs of toxicity at the doses evaluated. There were no abnormal signs, behavioral changes, or macroscopic alterations at any time during the observation period. However, HAE at the highest doses (1000 and $2000 \mathrm{mg} / \mathrm{kg}$ ) given intraperitoneally caused death preceded by observable adverse symptoms. These doses are, respectively, 10 and 20 times the minimum dose which gave gastric protection $(100 \mathrm{mg} / \mathrm{kg}$ p.o.) in the experimental ulcer model used. This suggests that the extract has a wide safety window. The absence of any deleterious symptoms with oral use denotes low toxicity for this preparation when administrated in single doses.

Serum ALT and AST activities are used as indicators of chemically induced liver damage [15]. The ALT and AST values of our control (saline) group were similar to other reports $[16,17]$. Results of the sub-chronic study revealed that there were significant $(P<0.05)$ increases in the means of serum ALT and AST levels in the HAE group when compared to the saline group. The literature shows that 2- to 3-fold increases in ALT levels above the upper limit of normal are needed to be considered indicative of hepatocellular injury [18]. Our study results did not reach these values (1.78 and 1.36 times the saline values of ALT and AST, respectively), and we compared it to mean, not to upper limits. Moreover, these parameters cannot be evaluated in isolation. The determination of this kind of druginduced toxic effect must be based on the magnitude of the changes in all concurrently evaluated parameters [18]. Other parameters evaluated in our sub-chronic essay (macroscopic organ evaluation, serum lipase and amylase, body mass changes in time, blood parameters and liver mass) did not shown any alterations. Furthermore, the dose used in sub-chronic toxicity was 4 times the therapeutic dose used in this report (400 vs. $100 \mathrm{mg} / \mathrm{kg}$ ). Pancreatic function indicators, amylase and lipase, did not differ between the HAE and saline groups. These considerations indicate a suitable safety margin for the oral administration of HAE. 

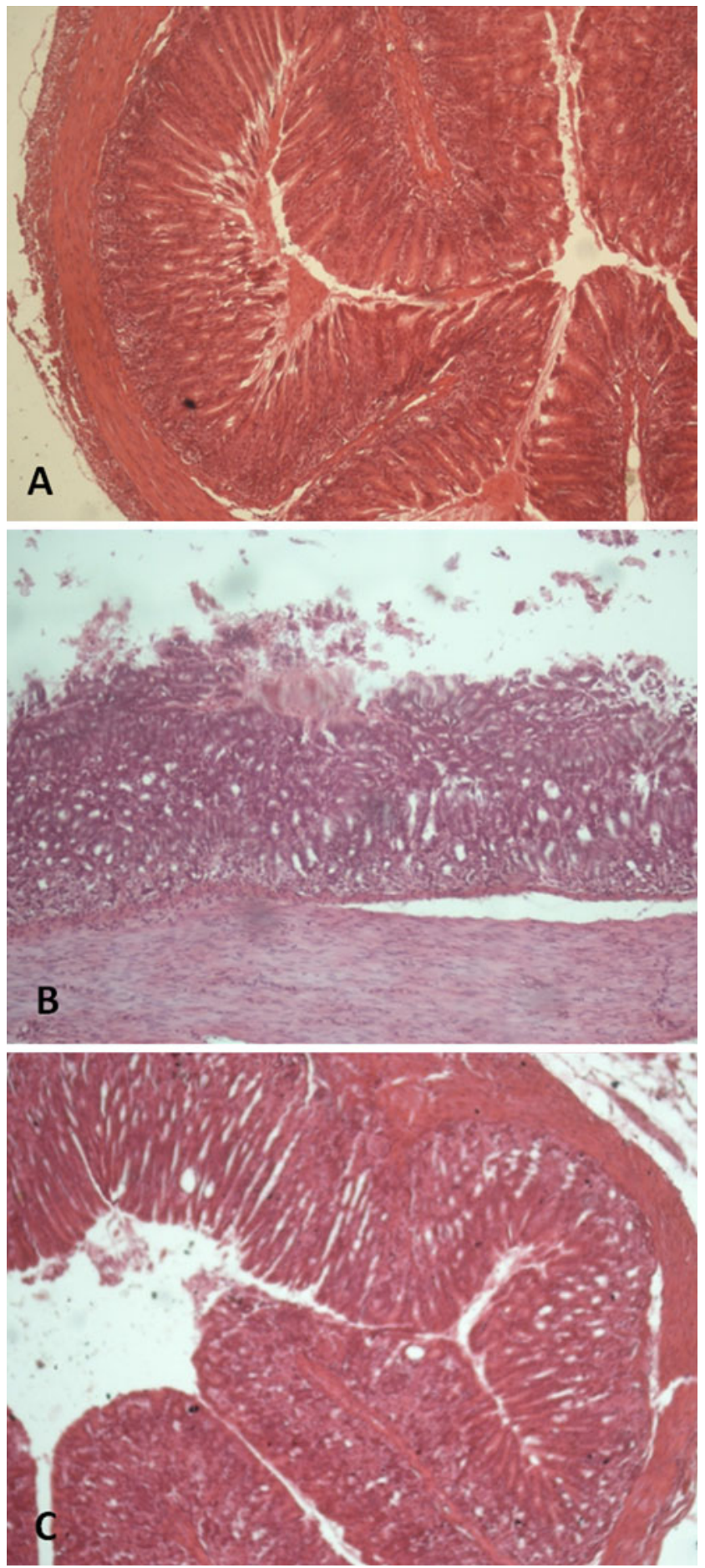

Fig. 2 Photomicrographs of gastric mucosa: a non-treated group with normal conformation of mucosa; $\mathbf{b}$ saline group (animals that received indomethacin + saline) showing loss of papillae conformation, with epithelial disruption and gastric lumen enhancement; c animals treated with indomethacin + HAE $100 \mathrm{mg} / \mathrm{kg}$, showing almost totally anatomical conformation, preservation of papillae and gastric luminal space $(\mathrm{H} \& \mathrm{E} \times 10)$
Table 3 Effects of HAE on gastric histological assessment after indomethacin challenge

\begin{tabular}{ll}
\hline Treatments & $\begin{array}{l}\text { Inflammatory cells } \\
\text { score }(0-4)\end{array}$ \\
\hline Not treated $^{\mathrm{a}}$ & 0 \\
Saline & $2(1-3)$ \\
Omeprazole $30 \mathrm{mg} / \mathrm{kg}$ & $1(0-1)^{* *}$ \\
HAE $100 \mathrm{mg} / \mathrm{kg}$ & $1(0-1)^{* *}$ \\
HAE $400 \mathrm{mg} / \mathrm{kg}$ & $1(0-1)^{* *}$ \\
\hline
\end{tabular}

Data shown are medians with minimum and maximum scores shown in brackets. Kruskal-Wallis nonparametric test followed by Dunn's test was used for multiple comparisons of histological assessment

HAE, Chresta martii hydroalcoholic extract

$* * P<0.05$ versus saline group

${ }^{a}$ Non-treated group received no indomethacin

Our results clearly demonstrated that HAE protects against indomethacin-induced gastric mucosal lesions in mice, as shown by a significant decrease in the mean scores in comparison to the saline group. The integrity of gastric mucosal defense depends on continuous generation of prostaglandin $\mathrm{E}_{2}\left(\mathrm{PGE}_{2}\right)$ and prostacyclin $\left(\mathrm{PGI}_{2}\right)$, mediated by cyclooxygenases 1 (COX1) and 2 (COX2), which catalyze the rate-limiting step in the conversion of arachidonic acid to prostaglandins (PGs). $\mathrm{PGE}_{2}$ and $\mathrm{PGI}_{2}$ are both potent vasodilators and control many aspects of gastric mucosal defense and healing $[19,20]$. These prostaglandins play an important role in maintenance of gastric mucosa blood flow, stimulation of mucus secretion, inhibition of neutrophil adherence and activation, and in the ability to protect the stomach against ulcerogenic agents [21-24]. Leukotrienes, having the same precursor as PGs (arachidonic acid), play an important role in gastric mucosa protective functions. Leukotriene production is related to vasoconstriction and neutrophil chemoattraction [25]. Inhibition of COX causes an imbalance in mucosal levels of leukotrienes and prostaglandins, favoring the production of the former [14].

According to Souza et al. [26], indomethacin-induced gastric lesions are dependent on neutrophil infiltration and nitric oxide (NO) generation through the inducible nitric oxide pathway. Our results of the histological assessment reveal that $\mathrm{HAE}(100$ or $400 \mathrm{mg} / \mathrm{kg}$, p.o.) reduced inflammatory cell migration to the gastric mucosa (Table 3). This reduction in neutrophils may, perhaps, contribute to the gastroprotection exhibited by the HAE.

Previous studies [27] showed that reactive oxygen species (ROS) play a vital role in indomethacin-induced gastric damage via oxidation of important cellular biomolecules such as lipids, proteins and DNA. The ROSmediated degradation of the cell membrane results in the formation of lipid peroxides and initiates a variety of 
Fig. $3 \mathrm{HPLC/UV/APCI-MS}$ chromatogram of $C$. martii hydroalcoholic extract (C-18 column, UV $254 \mathrm{~nm}$, APCI positive mode, mobile phase: $\mathrm{MeOH}-\mathrm{H}_{2} \mathrm{O}+$ formic acid $0.2 \%$ in gradient mode) and elucidated structure for compound $\mathbf{1}$

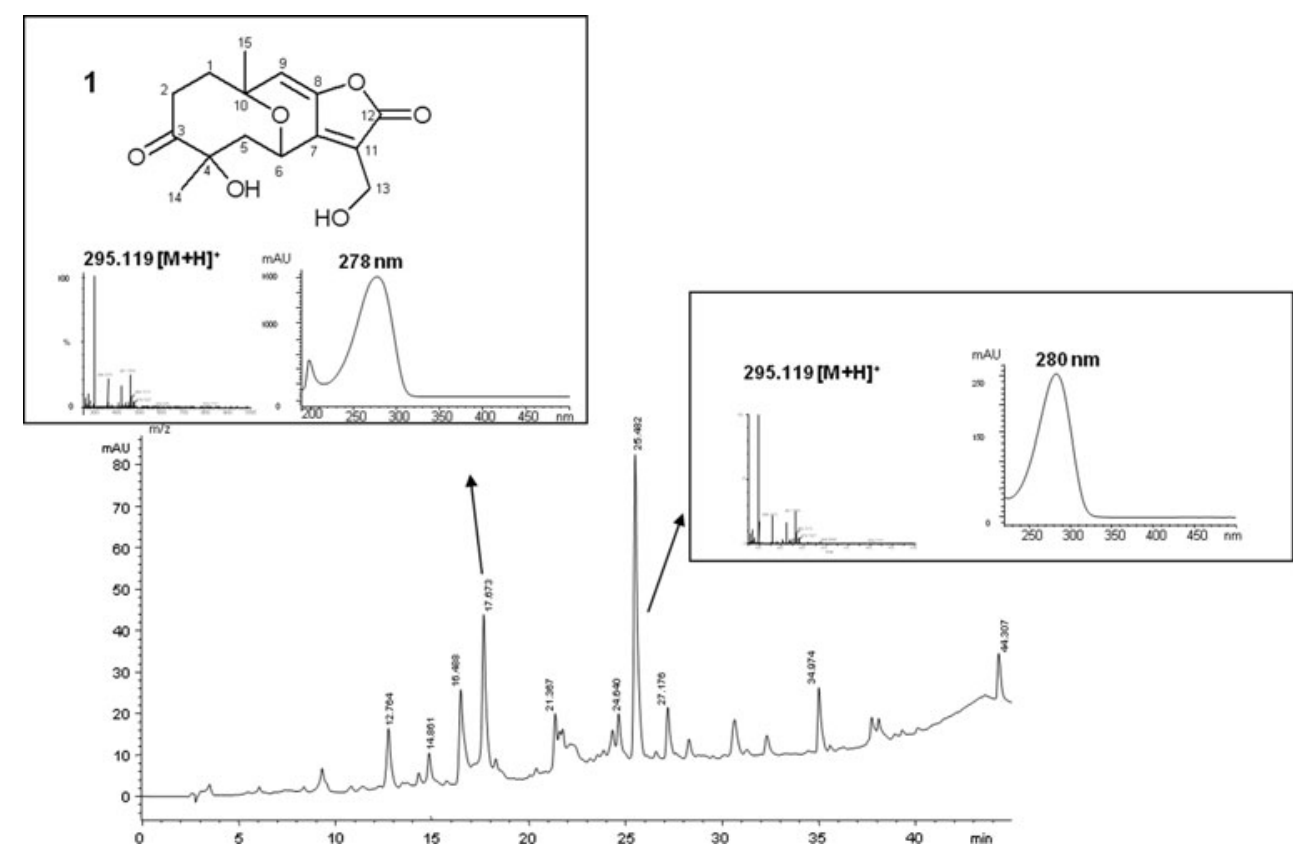

Table 4 NMR data of compound 1 in $\mathrm{CD}_{2} \mathrm{Cl}_{2}$

\begin{tabular}{lrll}
\hline Position & ${ }^{13}$ C NMR & ${ }^{1} \mathrm{H}$ NMR & HMBC $\left({ }^{1} \mathrm{H} \rightarrow{ }^{13} \mathrm{C}\right)$ \\
\hline 1 & 38.7 & $2.04-2.51$ & $\mathrm{C}-2, \mathrm{C}-3, \mathrm{C}-10, \mathrm{C}-15$ \\
2 & 33.9 & $2.54-2.62$ & $\mathrm{C}-3, \mathrm{C}-4, \mathrm{C}-10$ \\
3 & 213.1 & & \\
4 & 76.2 & & \\
5 & 47.5 & $2.73-2.83$ & $\mathrm{C}-3, \mathrm{C}-4$ \\
6 & 67.2 & 5.43 & $\mathrm{C}-5, \mathrm{C}-7, \mathrm{C}-8, \mathrm{C}-10$ \\
7 & 146.7 & & \\
8 & 145.1 & & \\
9 & 113.6 & 5.83 & $\mathrm{C}-7, \mathrm{C}-8, \mathrm{C}-10$ \\
10 & 74.7 & & \\
11 & 121.6 & & $\mathrm{C}-7, \mathrm{C}-11, \mathrm{C}-12$ \\
12 & 168.5 & & $\mathrm{C}-3, \mathrm{C}-4, \mathrm{C}-5$ \\
13 & 56.0 & 4.51 & $\mathrm{C}-1, \mathrm{C}-9, \mathrm{C}-10$ \\
14 & 26.7 & 1.38 & \\
15 & 27.2 & 1.36 & \\
\hline
\end{tabular}

deleterious events, including mucosal lesions, increased vascular permeability and depletion of the mucus layer [28]. Nonprotein sulfhydryl groups, such as glutathione, promote cytoprotection by preventing free-radical oxidative damage in various tissues, including the gastric mucosa [29]. Indomethacin causes gastric erosions with increased lipid peroxidation and decreased glutathione peroxidase activity [27].

Some species from Asteraceae genera (Eremanthus erythropappus, Baccharis illinita and Baccharis trimera, Senecio brasiliensis) have demonstrated anti-ulcerogenic activity without deleterious side effects [3, 30-32]. Active

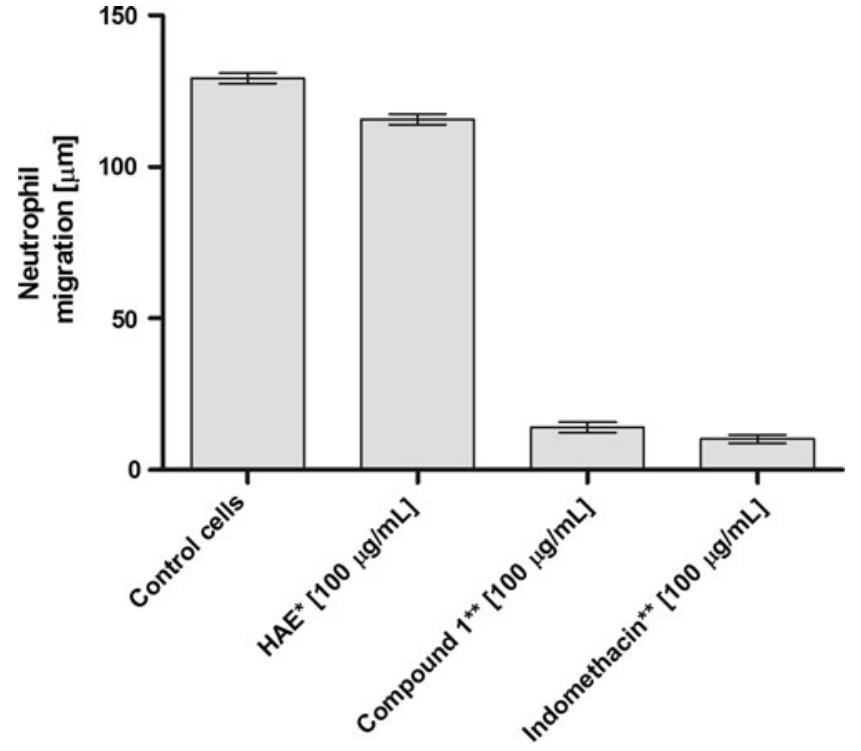

Fig. 4 Effect of HAE and compound $\mathbf{1}$ on in-vitro neutrophil migration towards a chemotactic factor (lipopolysaccharide) gradient in Boyden chamber chemotaxis assay. Positive control: indomethacin; $* P<0.05 ; * * P<0.001$

compounds of various plants, such as flavonoids, triterpenes and tannins, may be regarded as possible active substances against gastric lesions [33]. In our study, we demonstrated the presence of sesquiterpene lactones in C. martii HAE. Some authors have demonstrated that sesquiterpene lactones have gastroprotective effects in experimental models of ulcer [34-39]. In fact, sesquiterpene lactones are related to preservation of endogenous non-protein sulfhydryl groups such as glutathione [40]. These compounds can be related to the gastroprotective 
effect observed in our study. The isolated sesquiterpene lactone $\mathbf{1}$ was able to significantly inhibit neutrophil migration in a Boyden chamber in-vitro assay. This result corroborates the hypothesis that sesquiterpene lactones of this kind are responsible for the observed gastroprotection of HAE.

In conclusion, the low toxicity and the gastroprotective effect of $C$. martii HAE were demonstrated in mice, supporting the traditional use of this plant to treat gastric disorders. This plant provided a new sesquiterpene lactone with neutrophil antichemotactic activity. According to the HPLC/UV/MS fingerprint of $C$. martii HAE, this new plant species seems to be promising in providing new sesquiterpene lactones to be investigated individually for their complete structure elucidation and mechanisms of action in gastric protection.

Acknowledgments This work was supported by Conselho Nacional de Desenvolvimento Científico e tecnológico (CNPq), Fundação Cearense de Apoio ao Desenvolvimento Científico e Tecnológico (FUNCAP), Programa Rede Nordeste de Biotecnologia (RENORBIO) and the Swiss National Science Foundation (Grant no. 200010-100083 to K. Hostettmann).

\section{References}

1. Wang YR, Richter JE, Dempsey DT (2010) Trends and outcomes of hospitalizations for peptic ulcer disease in the United States, 1993 to 2006. Ann Surg 251:51-58

2. Barocelli E, Chiavarini M, Ballabeni V, Barlocco D, Vianello P, Dal Piaz V, Impicciatore M (1997) Study of the antisecretory and antiulcer mechanisms of a new indenopirydazinone derivative in rats. Pharmacol Res 35:487-492

3. Toma W, Trigo JR, Paula ACB, Brito ARMS (2004) Preventive activity of pyrrolizidine alkaloids from Senecio brasiliensis (Asteraceae) on gastric and duodenal induced ulcer on mice and rats. J Ethnopharmacol 95:345-351

4. Robinson H (1980) Notes on the Lychnophorine genera Chresta and Eremanthus. Phytologia 45:89-100

5. Agra MF, Silva KN, Basilio IJLD, Freitas PF, Barbosa-Filho JM (2008) Survey of medicinal plants used in the region Northeast of Brazil. Braz J Pharmacog 18:472-508

6. Almeida CFCBR, de Amorim ELC, Albuquerque UP, Maia MBS (2006) Medicinal plants popularly used in the Xingo region-a semi-arid location in Northeastern Brazil. J Ethnobiol Ethnomed $2: 1-7$

7. Almeida CFCBR, Silva TC, Amorim ELC, Maia MBS, Albuquerque UP (2005) Life strategy and chemical composition as predictors of the selection of medicinal plants from the caatinga (Northeast Brazil). J Arid Environ 62:127-142

8. Roque N, Gonçalves JM, Dematteis M (2008) A new species of the Brazilian genus Chresta (Asteraceae, Vernonieae) from Bahia. Bot J Linnean Soc 157:587-590

9. Miller LC, Tainter ML (1944) Estimation of the $\mathrm{ED}_{50}$ and its error by means of logarithmic-probit graph paper. Proc Soc Exp Biol Med 57:261-264

10. Szabo S, Trier JS, Brown A, Schnoor J (1985) Early vascular injury and increased vascular permeability in gastric mucosal injury caused by ethanol in the rat. Gastroenterology $88: 228-236$
11. Boyden S (1962) The chemotactic effect of mixtures of antibody and antigen on polymorphonuclear leukocytes. J Exp Med $15: 433-466$

12. Zigmond SH, Hirsch JH (1973) Leukocyte locomotion and chemotaxis. New methods for evaluation and demonstration of a cell-derived chemotactic factor. J Exp Med 137:387-410

13. Ramirez MR, Apel MA, Raseira MCB, Zuanazzi JÂS, Henriques AT (2011) Polyphenol content and evaluation of antichemotactic, antiedematogenic and antioxidant activities of Rubus sp. cultivars. J Food Biochem 35:1389-1397

14. Glasl S, Presser A, Gunbilig D, Werner I, Narantuya S, Haslinger E, Jurenitsch J, Kubelka W (2001) Highly hydroxylated guaianolides of Achillea asiatica and Middle European Achillea species. Phytochemistry 58:1189-1194

15. Drotman RB, Lawhorn GT (1978) Serum enzymes as indicators of chemical induced liver damage. Drug Chem Toxicol $1: 163-171$

16. Diniz MFFM, Medeiros IA, Santos HB, Oliveira KM, Vasconcelos THC, Aguiar FB, Toscano MG, Ribeiro EAN (2006) Haematological and biochemical parameter standardization of Swiss mice and Wistar rats. Rev Bras Ciências da Saúde 10(2):171-176

17. Mazzaccara C, Labruna G, Cito G, Scarfò M, Felice M, Pastore L, Sacchetti L (2008) Age-related reference intervals of the main biochemical and hematological parameters in C57BL/6J, 129SV/ EV and $\mathrm{C} 3 \mathrm{H} / \mathrm{HeJ}$ mouse strains. PLoS ONE 3(11):e3772

18. Boone L, Meyer D, Cusick P, Ennulat D, Bolliger AP, Everds N, Meador V, Elliott G, Honor D, Bounous D, Jordan H (2005) Selection and interpretation of clinical pathology indicators of hepatic injury in preclinical studies. Vet Clin Pathol 34(3): 182-188

19. Musumba C, Pritchard DM, Pirmohamed M (2009) Review article: cellular and molecular mechanisms of NSAID-induced peptic ulcers. Aliment Pharmacol Ther 30:517-531

20. Wallace JL (2008) Prostaglandins, NSAIDs, and gastric mucosal protection: why doesn't the stomach digest itself? Physiol Rev $88: 1547-1565$

21. Chandranath SI, Bastaki SMA, Singh J (2002) A comparative study on the activity of lansoprazole, omprazole and PD-136450 on acidified ethanol- and indomethacin-induced gastric lesions in the rat. Clin Exp Pharmacol Physiol 29:173-180

22. Ferreira SH, Moncada S, Vane JR (1973) Some effects of inhibiting endogenous prostaglandin formation on the responses of the cat spleen. Braz J Pharmacol 47:48-58

23. Suleyman H, Albayrak A, Bilici M, Cadirci E, Halici Z (2010) Different mechanisms in formation and prevention of indomethacin-induced gastric ulcers. Inflammation 33:224-234

24. Wallace JL (2001) Mechanisms of protection and healing: current knowledge and future research. Am J Med 110:19S-23S

25. Lutnicki K, Szpringer E, Czerny K, Ledwozyw A (2001) Effects of ethanol and arachidonic acid pathway inhibitors on the effectiveness of gastric mucosa cytoprotection. Folia Morphol (Warsz) 60:47-56

26. Souza M, Mota J, Oliveira R, Cunha F (2008) Gastric damage induced by different doses of indomethacin in rats is variably affected by inhibiting iNOS or leukocyte infiltration. Inflamm Res 57:28-33

27. Chattopadhyay I, Bandyopadhyay U, Biswas K, Maity P, Banerjee RK (2006) Indomethacin inactivates gastric peroxidase to induce reactive-oxygen-mediated gastric mucosal injury and curcumin protects it by preventing peroxidase inactivation and scavenging reactive oxygen. Free Radic Biol Med 40:1397-1408

28. Hanan E-A (2010) Coenzyme Q10: A novel gastroprotective effect via modulation of vascular permeability, prostaglandin E2, nitric oxide and redox status in indomethacin-induced gastric ulcer model. Eur J Pharmacol 649:314-319 
29. Szabo S, Nagy L, Plebani M (1992) Glutathione, protein sulfhydryls and cysteine proteases in gastric mucosal injury and protection. Clin Chim Acta 206:95-105

30. Baggio CH, Freitas CS, Rieck L, Marques MCA (2003) Gastroprotective effects of a crude extract of Baccharis illinita DC in rats. Pharmacol Res 47:93-98

31. Dias LFT, Melo ES, Hernandes LS, Bacchi EM (2009) Antiulcerogenic and antioxidant activities of Baccharis trimera (Less) DC (Asteraceae). Braz J Pharmacogn 19:309-314

32. Silverio MS, Sousa OV, Del-Vechio-Vieira G, Miranda MA, Matheus FC, Kaplan MAC (2008) Pharmacological properties of the ethanol extract from Eremanthus erythropappus (DC.) McLeisch. Braz J Pharmacog 18:430-435

33. Repetto MG, Llesuy SF (2002) Antioxidant properties of natural compounds used in popular medicine for gastric ulcers. Braz $\mathbf{J}$ Med Biol Res 35:523-534

34. Giordano OS, Guerreiro E, Pestchanker MJ, Guzman J, Pastor D, Guardia T (1990) The gastric cytoprotective effect of several sesquiterpene lactones. J Nat Prod 53:803-809

35. Giordano OS, Pestchanker MJ, Guerreiro E, Saad JR, Enriz RD, Rodriguez AM, Juregui EA, Guzmn J, Mara AO, Wendel GH (1992) Structure-activity relationship in the gastric cytoprotective effect of several sesquiterpene lactones. $J$ Med Chem 35:2452-2458

36. Gürbüz I, Yesilada E (2007) Evaluation of the anti-ulcerogenic effect of sesquiterpene lactones from Centaurea solstitialis L. ssp. solstitialis by using various in vivo and biochemical techniques. J Ethnopharmacol 112:284-291

37. Heinrich M, Robles M, West JE, Ortiz de Montellano BR, Rodriguez E (1998) Ethnopharmacology of Mexican Asteraceae (Compositae). Annu Rev Pharmacol Toxicol 38:539-565

38. Tournier H, Schinella G, de Balsa EM, Buschiazzo H, Manez S, Mordujovich de Buschiazzo P (1999) Effect of the chloroform extract of Tanacetum vulgare and one of its active principles, parthenolide, on experimental gastric ulcer in rats. J Pharm Pharmacol 51:215-219

39. Yesilada E, Gürbüz I, Bedir E, Tatli I, Khan IA (2004) Isolation of anti-ulcerogenic sesquiterpene lactones from Centaurea solstitialis L. ssp. solstitialis through bioassay-guided fractionation procedures in rats. J Ethnopharmacol 95:213-219

40. Guardia T, Guzman JA (1994) Mucus synthesis and sulfhydryl groups in cytoprotection mediated by dehydroleucodine, a sesquiterpene lactone. J Nat Prod 57(4):507-509 